Short Research Article

\title{
Evaluation and Adoption Scope of Rotary Power Weeder for Weed Management in Vegetable Crops
}

\author{
N. S. Chandel ${ }^{1 *}$, H. Tripathi ${ }^{1}$ and V. K. Tewari ${ }^{2}$ \\ ${ }^{1}$ Central Institute of Agricultural Engineering, Berasia Road, Nabi Bagh, Bhopal, M.P. (462 038), India \\ ${ }^{2}$ IIT-Kharagpur, West Bengal (721 320), India
}

\section{Article History}

Manuscript No. AR958

Received in $9^{\text {th }}$ October, 2014

Received in revised form $20^{\text {th }}$ July, 2015

Accepted in final form $5^{\text {th }}$ August, 2015

\section{Correspondence to}

"E-mail: narendracae@gmail.com

\section{Keywords}

Field capacity, vegetable cultivation, weed management, farmer's feedback.

\begin{abstract}
In this study, a commercial self-propelled rotary power weeder was evaluated in wide space line sown three vegetable crops i.e. tomato (Solanum lycopersicum), yard long bean (Vigna sesquipedalis) and okra (Hibiscus esculenta) crop at research field of Agricultural and Food Engineering Department IIT Kharagpur, West Bengal during 2010-13. The weeder was installed with $4 \mathrm{~kW}$ air cooled diesel engine with 3 forward and 2 reverse speed transmission systems. Twelve L-shape weeding blades on three flanges was attached at rearward of the self-propelled unit. Field capacity, field efficiency, weeding efficiency and plant damage was observed during the field evaluation. The observed field efficiency of self-propelled rotary weeder was 86.7, 82.4 and $87.2 \%$ and effective field capacity was $0.092,0.080,0.096 \mathrm{ha} \mathrm{h}^{-1}$ at a forward speed of 2.3, 2.0 and $2.4 \mathrm{~km} \mathrm{~h}^{-1}$ in tomato, yard long bean and okra, respectively. Effective working width of operation was $400 \mathrm{~mm}$. The depth of operation was 53, 46 and $50 \mathrm{~mm}$ for tomato, yard long bean and okra, respectively. Weeding efficiency in tomato, yard long bean and okra was found as 96, 94 and 97\%, respectively with plant damage of 1.6, 2.8 and 1.9\%, respectively. Feedback from 35 respondents was conducted for adoption of rotary power weeder in vegetable crop. Analysis shows that more than $96 \%$ farmers were willing to the adoption of rotary power weeder through the custom hiring services.
\end{abstract}

\section{Introduction}

Vegetables are good source of farm income than other traditional crops. They play an important role in human diet with rich sources of vitamins and other essential nutrients. Vegetable crop establishment is necessary to eliminate the effect of weeds, pests and disease infestation to provide suitable conditions for optimum yield of crops. Weeds are the bounding factors of agricultural production, which compete crop plants with their rapid growth (Tamado and Milberg, 2000). Weed control measures must be put in place to check the growth and propagation of weeds. Chemical and mechanical weed control methods are viable alternatives; however, the environmental impacts of herbicides made chemical methods unsustainable. Weeding operation is viable solution for the removal of unwanted plants in the crop production (Sharma et al., 2014). Wages rate for weeding and intercultural operation in the state of West Bengal is about ₹ 175 Day $^{-1}$ (Singh et al., 2013). So the cost of weed management was highest in cost of production. It is one of the tedious operations in vegetable production.
The earliest, simplest and most popular weed management method is manual weed control in vegetable production. Now advanced hand tools like khurpi, wheel hoe, hand hoe, etc. are mostly used for weeding and intercultural operations. These weeding methods were expensive, time consuming and labour intensive (Weide et al., 2008). There was an acute labor shortage, which results in increased labor wages and delay in the weeding operation. The introduction of chemical weed control along with manual weeding method has eased these undesirable factors (Lhungdim et al., 2013). However, the emergence of herbicide-resistant weeds has bad impact on environment. In chemical weeding weedicide application was selective, expensive, and hazardous. Increasing the demand for chemical free foods has led to investigate the alternative methods for weed control. Mechanical weed control is very effective and best suitable alternative with reducing drudgery over manual weeding. It removes the weeds ensuring soil aeration and water intake capacity of soil surface.

Mechanical weeding has increased yield of field crop and 
vegetables rather than using hand weeding (Senthillkumar, 2003; Alizadeh, 2011). Rotary power weeder works better in respect of average working depth $(56.7 \mathrm{~mm})$ which is $16.67 \%$ more than bullock drawn blade weeder (Tewari et al., 2014). Plant damage was increased with decrease in moisture content below $11.63 \%$ (Goel et al., 2008). There are so many studies conducted on performance of manual, animal and power operated weeders in grain crop. But no study was conducted on performance of self-propelled rotary weeder in vegetable cultivation. Keeping, the above facts in mind the objective of this study was to evaluate the performance and the scope of commercialization of self-propelled rotary weeder in line sown vegetable crops in the state of West Bengal.

\section{Materials and Methods}

A commercially available self-propelled rotary power weeder was selected for this study at Agricultural and Food Engineering Department, IIT Kharagpur, West Bengal during year 2010 to 2013. The weeder was installed with $4 \mathrm{~kW}$ air cooled diesel engine with 3 forward and 2 reverse speed transmission systems. $12 \mathrm{~L}$-shape weeding blades on three flanges was attached at rearward of the self-propelled unit. Handle and the control levers are provided to control the direction and speed of operation. Height of weeder was adjustable according to height of operator between $400-1140 \mathrm{~mm}$ from the ground level. Three wide row line sown vegetable crops i.e. tomato, yard long bean and okra were used in this study at research farm. A 0.5 ha plot was selected for the field trials of each crop. The soil type was sandy clay loam. Row to row spacing of tomato, yard long bean and okra planting was 650,700 and $600 \mathrm{~mm}$, respectively. Trials were carried out after 22 days of planting in tomato and after 24 days of sowing in okra and yard long bean. The field was infested mostly with grassy weeds such as Echinochloa crusgalli, Trifolium repens and Cyperus rotundus. At that stage, the crop height and the density of weeds were measured with a standard quadrate. Soil moisture, cone index and bulk density were also measured and recorded.

Bulk density of soil was measured by core cutter method and cone index was measured by a digital cone penetrometer. Three soil samples were collected from each test plots with the help of soil sampling auger for moisture measurement. Initial weight (W1) of each sample was taken on digital balance and dried it at $105^{\circ} \mathrm{C}$ for 8 hours. Dried sample were collected from oven and final weight (W2) was taken. Moisture content (MC) on dry basis has been calculated by equation (1) (Chen, 2003). In order to determine the weeding efficiency, 10 randomly patches of $1 \times 1 \mathrm{~m}$ size was taken and the number of weeds were counted before and after weeding operation. The weeding efficiency

$$
\mathrm{MC}(\mathrm{db})=\frac{\mathrm{W} 1-\mathrm{W} 2}{\mathrm{~W} 2} \times 100
$$

(Remesan et al., 2007) was calculated by the equation (2).

Where, WE is the weeding efficiency of the weeder (\%), N1

$$
W E=\frac{N 1-N 2}{N 2} \times 100
$$

and N2 are the number of weeds before and after weeding operation, respectively.

To determine the plant damage, the numbers of damaged plants were counted randomly selecting $1 \mathrm{~m}$ length of crop row at 10 locations of each plot. Then, plants damage $\%$ as a quality of work done (Tewari et al., 1993) was obtained by the equation (3).

Where, DP is the plants damage (\%), Q1 and Q2 are the

$$
\mathrm{DP}=\frac{\mathrm{Q} 1}{\mathrm{Q} 2} \times 100
$$

damaged plants and total number of plants per unit length, respectively.

Effective field capacity $\left(\mathrm{C}_{\mathrm{e}}\right)$, field efficiency $\left(\mathrm{F}_{\mathrm{e}}\right)$ and work capacity $\left(\mathrm{W}_{\mathrm{c}}\right)$ were calculated by the following equations (Hunt, 1995)

$$
\mathrm{Ce}=\frac{\mathrm{S} \times \mathrm{W} \times \mathrm{E}}{10} \times 100 \quad \mathrm{Fe}=\frac{\mathrm{Te}}{\mathrm{Tt}} \times 100 \quad \mathrm{Wc}=\frac{1}{\mathrm{Ce}}
$$

Where, Ce is the effective field capacity $\left(\mathrm{ha} \mathrm{h}^{-1}\right), \mathrm{S}$ is the travel speed of the weeder $\left(\mathrm{km} \mathrm{h}^{-1}\right), \mathrm{W}$ is the width of operation $(\mathrm{m})$, $\mathrm{Fe}$ is the field efficiency of the weeder (\%), $\mathrm{T}_{t}$ and $\mathrm{T}_{\mathrm{e}}$ are the total and useful working time (h), respectively and $\mathrm{Wc}$ is the working capacity $\left(\mathrm{h} \mathrm{ha}^{-1}\right)$.

The potential of equipment could be harnessed effectively by demonstration to the target group. For this a questionnaire was framed for getting feedback from farm workers and vegetable grower (respondents) regarding adoption of self-propelled rotary weeder over conventional methods. The response of 35 respondents on operation of this equipment and reasons for adoption and purchasing are given in Table 1. The cost of operation per hour for operating self-propelled rotary weeder was calculated by straight line depreciation method (Singh, 2007).

\section{Results and Discussion}

\subsection{Work capacity}

Soil moisture content of the test field was found as $15.42 \%$ (db). Bulk density of the field after operation was found as 1.32 $\mathrm{g} \mathrm{cc}^{-1}$ and value of cone index before and after the weeding operation was given in (Table 1). Effective width of weeder was $400 \mathrm{~mm}$ and average depth of operation in tomato, yard long bean and okra was 53,46 , and $50 \mathrm{~mm}$, respectively (Table 1 ). Weeding depth in yard long bean was less due to hardness 
of soil. The effective field capacity of the power weeder was $0.092,0.08$, and $0.096 \mathrm{ha} \mathrm{h}^{-1}$ for tomato, yard long bean and okra, respectively (Table 1). The effective field capacity and field efficiency in yard long bean was quite less than tomato and okra due to tilted crop and high weed infestation. The field efficiency of weeder was $86.7,82.4$, and $87.2 \%$ in tomato, yard long bean and okra field, respectively. Minimum time required for weeding in line sown crop was $10.4 \mathrm{~h} \mathrm{ha}^{-1}$ in okra. The average fuel consumption was relatively high ( 0.43 and

Table 1: Results of the performance evaluation of selfpropelled rotary weeder in different vegetable crops

\begin{tabular}{|c|c|c|c|c|}
\hline \multirow[t]{2}{*}{ Parameters } & \multirow[t]{3}{*}{ Unit } & \multicolumn{3}{|c|}{ Performance } \\
\hline & & Tomato & $\begin{array}{l}\text { Yard } \\
\text { long } \\
\text { bean }\end{array}$ & Okra \\
\hline Soil type & & $\begin{array}{c}\text { Sandy } \\
\text { clay } \\
\text { loam }\end{array}$ & $\begin{array}{c}\text { Sandy } \\
\text { clay } \\
\text { loam }\end{array}$ & $\begin{array}{c}\text { Sandy } \\
\text { clay } \\
\text { loam }\end{array}$ \\
\hline $\begin{array}{l}\text { Cone index } \\
\text { (before testing) }\end{array}$ & $\mathrm{k} \mathrm{pa}$ & 270 & 285 & 260 \\
\hline $\begin{array}{l}\text { Cone index } \\
\text { (after testing) }\end{array}$ & $\mathrm{k}$ pa & 90 & 110 & 90 \\
\hline $\begin{array}{l}\text { Bulk density } \\
\text { (after testing) }\end{array}$ & $\mathrm{g} \mathrm{cm}^{-3}$ & 1.32 & 1.32 & 1.32 \\
\hline $\begin{array}{l}\text { Theoretical width } \\
\text { of operation }\end{array}$ & $\mathrm{mm}$ & 460 & 460 & 460 \\
\hline $\begin{array}{l}\text { Effective Width } \\
\text { of operation }\end{array}$ & $\mathrm{mm}$ & 400 & 400 & 400 \\
\hline Depth of weeding & $\mathrm{mm}$ & 53 & 46 & 50 \\
\hline $\begin{array}{l}\text { Row to row } \\
\text { spacing of crop }\end{array}$ & $\mathrm{mm}$ & 650 & 700 & 600 \\
\hline Forward speed & $\mathrm{km} \mathrm{h}^{-1}$ & 2.3 & 2.0 & 2.4 \\
\hline $\begin{array}{l}\text { Theoretical field } \\
\text { capacity }\end{array}$ & ha $h^{-1}$ & 0.106 & 0.097 & 0.11 \\
\hline $\begin{array}{l}\text { Effective field } \\
\text { capacity }\end{array}$ & ha $h^{-1}$ & 0.092 & 0.08 & 0.096 \\
\hline Field efficiency & $\%$ & 86.7 & 82.4 & 87.2 \\
\hline Work capacity & $\mathrm{h} \mathrm{ha}^{-1}$ & 10.9 & 12.5 & 10.4 \\
\hline Weeding efficiency & $\%$ & 96 & 94 & 97 \\
\hline Plant damage & $\%$ & 1.6 & 2.8 & 1.9 \\
\hline Fuel consumption & $1 \mathrm{~h}^{-1}$ & 0.40 & 0.43 & 0.40 \\
\hline Fuel consumption & $1 \mathrm{ha}^{-1}$ & 4.36 & 5.4 & 4.16 \\
\hline $\begin{array}{l}\text { Labour require- } \\
\text { ment }\end{array}$ & $\operatorname{man}^{-1} h^{-1}$ & 12 & 14 & 12 \\
\hline Cost of operation & $₹ \mathrm{ha}^{-1}$ & 594 & 608 & 589 \\
\hline Cost of operation & $₹ \mathrm{~h}^{-1}$ & 45 & 45 & 45 \\
\hline
\end{tabular}

$5.41 \mathrm{ha}^{-1}$ ) in yard long bean and almost same consumption was recorded in tomato and okra crop weeding. The weeder have small turning radius which was $0.79 \mathrm{~m}$, helpful in weeding in vegetable fields. Intra row weeding operation by self-propelled rotary weeder in tomato and yard long bean is shown in (Figure 1).

\subsection{Weeding quality and cost of operation}

Field performance of self-propelled rotary weeder in different vegetable crops are shown in (Figure 2). Damages like cut, uproot and graze etc., to the vegetable plants during operation with weeder were also observed. No stem damage was found in whole weeding operation due to wide inter row spacing of crop. Plant damage was higher $(2.8 \%)$ in yard long bean crop due to the more branches and tilted plants, whereas, in tomato it was $1.6 \%$ crop. During field operation it observed that clean weeding was obstructed due to large and fibers weed entangled in both end of rotary shaft. There was no clogging of weeds observed in middle portion. No mechanical damage was observed in the weeder during field operation. The cost of operation of weeder in different crop was calculated by considering fixed cost and variable cost. The lowest cost of operation ₹ $589 \mathrm{ha}^{-1}$ was observed for okra. This may be due to higher field capacity and low cost of the developed weeder.

\subsection{Scope for commercialization}

The target group showed their keen interest to use rotary power weeder over the traditional method (Table 2). indicated the suitability in study area. The product was designed and developed, using Indian farm workers' anthropometric dimensions, which helped the subject to operate for longer duration. It was observed that the subject could operate the

Table 2: Feedback from respondents on adoption of power weeder in vegetable crop

\begin{tabular}{lll}
\hline Feedback of respondents & Average response of subjects \\
& $(\mathrm{N}=35), \%$ \\
\hline Operation of equipment & Ease in operation & 95 \\
& Safety in operation & 93 \\
& Fatigue in operation & 11 \\
Reasons for adoption & Higher output & 100 \\
& Negligible plant damages & 94 \\
& Cost effective & 95 \\
& Ease in movement & 89 \\
& Less chances of weed & 95 \\
& trapping & \\
& Suitable for other than & 100 \\
& weeding & \\
Higher cost & 86 \\
Purchasing the equipment & Custom hiring & 96 \\
\hline
\end{tabular}



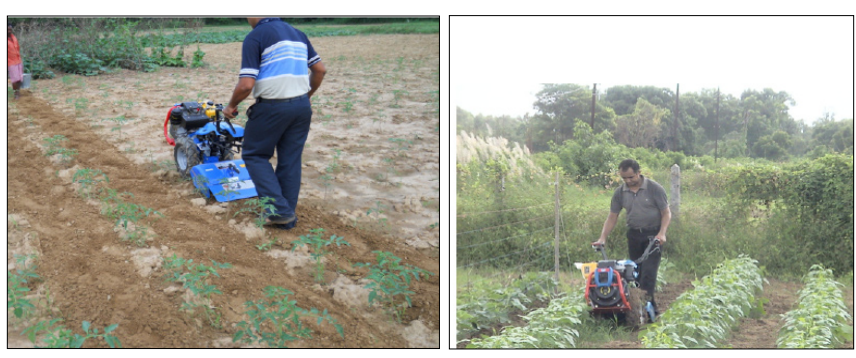

Figure1: Self-propelled rotary weeder operation in tomato and yard long bean field
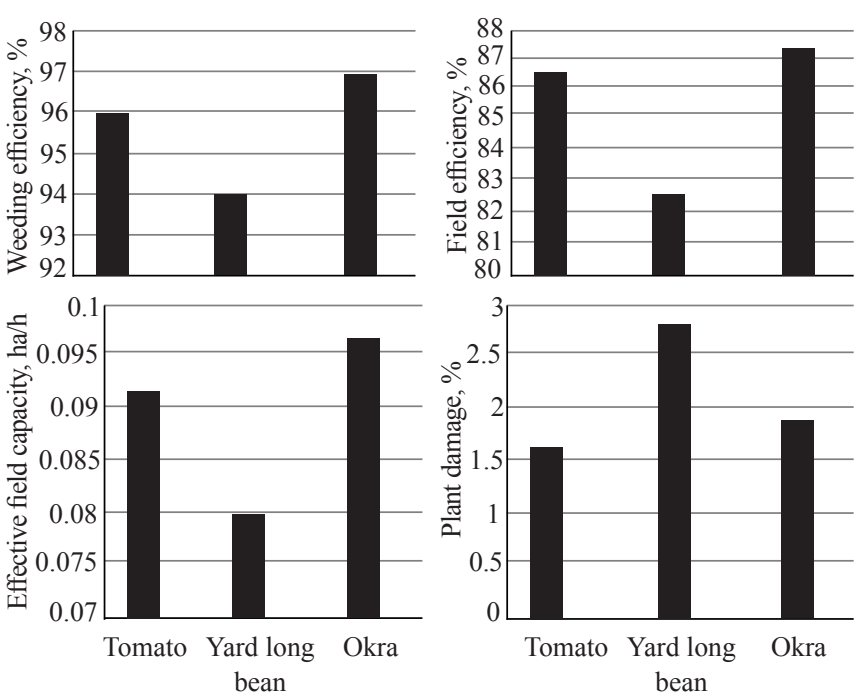

Figure 2: Field performance of self-propelled rotary weeder in different vegetable crops

self-propelled weeder easily (95\%) with less safety in operation (93\%). Higher output, and ease handling of equipment are the main reasons for adoptions in vegetable cultivation. The machine is simple in construction, repairable locally and eases in field operation. Custom hiring would be the right solution for the target group (96\%) in West Bengal. The weeder price was ₹ 88000.00 (1470 US\$) and this cost may be reduced up to $12 \%$ after its commercialization.

\section{Conclusion}

Rotary power weeder works satisfactorily. Weeding efficiency was more than $94 \%$ in all crops. The effective field capacity of weeder was highest in okra $\left(0.096 \mathrm{ha} \mathrm{h}^{-1}\right)$ than tomato and yard long bean. Turning radius of power weeder was small (about $0.79 \mathrm{~m}$ ) which was helpful in taking short turn without damaging the plants. At some places adoption of mechanical inter-row weeder was not supported by the existing cropping systems.

\section{References}

Alizadeh, M.R., 2011. Field performance evaluation of mechanical weeders in the paddy field. Scientific Research and Essays 6(25), 5427-5434.
Chen, C., 2003. Evaluation of air oven moisture content determination methods for rough rice. Biosystems Engineering 86(4), 447-457.

Goel, A.K., Behera, D., Behera, B.K., Mohanty, S.K., Nanda, S.K., 2008. Development and ergonomic evaluation of manually operated weeder for dry land crops, Agricultural Engineering International: the CIGR E-journal. Manuscript PM 08-09. X. September.

Hunt, D., 1995. Farm power and machinery management ( $9^{\text {th }}$ Edn.), Iowa State University Press. Ames, IA, USA.

Lhungdim, J., Singh, Y., Singh, R. Pd., 2013. Integration of chemical and manual weed management on weed density, yield and production economics of lentil (Lens culinaris Medikus). International Journal of Bio-resource and Stress Management 4(4), 593-598.

Remesan, R., Roopesh, M.S., Remya, N., Preman, P.S., 2007. Wet land paddy weeding-a comprehensive comparative study from South India. Agricultural Engineering International: the CIGRE journal 9, 1-21.

Senthillkumar, 2003. Effect of weed control methods on rice cultivars in Indian rice field. Journal of Biological Science 3, 119-123.

Sharmal, G., Shrivastava, A., Dhakre, D.S., Singh, D.P., 2014. Effect of weed management practices in chrysanthemum (Dendranthema grandiflora T.) under Chhattisgarh plains agro-climatic condition. International Journal of Bioresource and Stress Management 5(3), 400-403.

Singh, S., 2007. Farm machinery: principles and applications. Indian Council of Agricultural Research New Delhi 323330.

Tamado,T., Milberg, P., 2000. Weed flora in arable fields of eatern Ethiopia with emphasis on the occurrence of Parthenium hysterophorus. Weed Research 40, 507-512.

Tewari, V.K., Chandel, N.S., Vidhu, K.P., Tripathi H., 2014. Performance evaluation and scope of adoption of rotary power weeder in vegetable crops Agricultural Engineering Today, 38(3), 10-14.

Tewari, V.K., Datta, R.K., Murthy, A.S., 1993. Field performance of weeding blades of a manually operated push-pull weeder. Journal of Agricultural Engineering Research 55(2), 129141.

Weide, R.Y.V.D., Bleeker, P.O., Achten, V.T.J.M., Lotz, L.A.P., Fogelberg, F., Melander, B., 2008. Innovation in mechanical weed control in crop rows. Weed Research 48(3), 215224.

Singh, D., Negi, I.S., Jarial, R.C., 2013. Average daily wage rates for agricultural and non-agricultural occupations in rural India. Monthly statistics. Government of India ministry of labour and employment labour bureau Shimla/Chandigarh (September, 2013). Indian Labour Journal 54 (9), 957-968. 